\title{
LITERASI DIGITAL: Suatu Kemewahan Bagi UMKM Perikanan di Era Industri 4.0?
}

\author{
Oktiva Anggraini ${ }^{1)}$ dan Supriyanto ${ }^{2)}$ \\ 1)Prodi Administrasi Negara FISIPOL \\ Universitas Widya Mataram, Yogyakarta \\ oktivabiyan@yahoo.co.id \\ 2)Prodi Manajemen Fakultas Ekonomi \\ Universitas Widya Mataram, Yogyakarta
}

\begin{abstract}
Abstrak
Tujuan dari penelitian ini adalah mengkaji upaya Dinas Pertanian Tanaman Pangan Kelautan dan Perikanan Kabupaten Bantul dalam mengoptimalkan pengelolaan dan pemasaran produksi perikanan. Selain itu, untuk mengetahui akses UMKM perikanan terhadap digital marketing. Penelitian ini menggunakan pendekatan kualitatif deskriptif. Teknik pengumpulan data dengan indepth interview, teknik dokumentasi, FGD (Focus Group Discussion) dan observasi partisipatoris. Teknik analisis data kualitatif meliputi (a) pengumpulan data; b) reduksi data c) penyajian data; d) simpulan dan verifikasi. Hasil penelitian menunjukkan bahwa upaya Dinas Pertanian Tanaman Pangan Kelautan dan Perikanan Kabupaten Bantul dalam mengoptimalkan pengelolaan dan pemasaran Produksi Perikanan meliputi promosi hasil produksi perikanan kelautan; peningkatan kelembagaan Kelompok Pengolah dan Pemasar (Poklahsar), pelatihan Poklahsar dan monitoring mutu hasil perikanan yang beredar di masyarakat. Kendala yang dihadapi dalam penguasaan digital marketing sebagian besar disebabkan kekurangpahaman pelaku usaha tentang penggunaan internet dan tidak dimilikinya tenaga yang memahami teknologi informasi. Langkah strategis bagi penguatan UMKM dapat ditempuh melalui penambahan frekwensi pelatihan, studi banding dan mengintensifkan pendampingan literasi digital marketing pada kelompok pemasar.
\end{abstract}

Kata kunci: umkm perikanan, digital marketing, pemasaran, internet

\begin{abstract}
This study aims to examine the efforts of the Marine and Fisheries Food Crop Service Office of Bantul Regency in optimizing the management and marketing of fisheries production. In addition, to find out the access of fisheries SMME (Small Micro Medium Entreprise) to digital marketing. The study apllied qualitative descriptive research design. Data collection techniques through indepth interviews, documentation techniques, FGD (Focus Group Discussion) and participatory observation. Techniques for analyzing qualitative data include (a) data collection; b) data reduction c) data presentation; d) conclusion and verification.

The research results demonstrate that the Bantul Agriculture and Fisheries Food Service Office's efforts in optimizing the management and marketing of Fisheries Production included the promotion of marine fisheries products; institutional improvement of marketers group, holding of training for marketers and monitoring of fisheries product quality circulating in the community. The constraints faced in mastering digital marketing are largely due to the lack of understanding of marketer about internet usage and not having workers who understand information technology. Strategic steps for strengthening SMME can be pursued through the addition of frequency of training, comparative studies and intensifying mentoring of digital marketing literacy to groups.
\end{abstract}

Keywords: SMME of fisheries, digital marketing, marketing; internet

\section{PENDAHULUAN}

Revolusi industri era 4.0 merupakan era yang diwarnai oleh kecerdasan buatan (artificial intelegence) era super komputer rekayasa genetika, inovasi dan perubahan cepat yang berdampak pada ekonomi, industri, budaya dan pemerintahan serta politik. Arah pembangunan di era revolusi industri 4.0 menuju pada ekonomi digital dan teknologi, telah merubah pekerjaan manusia menjadi lebih cepat dan efisien. Literasi digital menjadi hal krusial di Era industri 4.0 sebab penguasaan teknologi informasi merupakan elemen penting bagi transformasi budaya, ekonomi, politik dan sosial. Teknologi dapat 
memberi sumbangsih besar jika masyarakat memiliki skill dan pemahaman yang baik tentang pemanfaatan teknologi. Dengan demikian, kondisi ini mengantarkan setiap orang memiliki literasi dalam pemanfaatan media digital.

Dalam kenyataannya, distribusi akses teknologi informasi masih belum merata dari aspek geografis maupun strata sosial. Pemanfaatan pemasaran melalui media digital (digital marketing) masih belum maksimal jika dibandingkan dengan pertumbuhan pengguna internet yang drastis.

Dari sisi gender, teknologi informasi identik dengan ranah laki-laki. Kesenjangan digital antara laki-laki dan perempuan selain terlihat dari kesenjangan penggunaan internet namun juga pada peran yang dilekatkan pada perempuan terkait dengan penggunaan internet.

Berdasarkan data APJII (Asosiasi Penyelenggara Jasa Internet Indonesia) tahun 2016 menunjukkan bahwa 132,7 juta dari total keseluruhan 256,2 juta peduduk Indonesia merupakan pengguna aktif internet. Pengguna internet laki-laki kuantitasnya lebih besar yakni $52,5 \%$ dibandingkan dengan pengguna perempuan sebesar 47,5\%. Jumlah pengguna ini meningkat di tahun 2017 menjadi 143,26 juta. Dari sisi peran, peran perempuan dalam konteks ruang publik lebih sering ditempatkan pada posisi administrasi dan bukan pada posisi strategis.

Pemanfaatan konsep pemasaran berbasis teknologi digital (digital marketing) memberi harapan bagi UMKM untuk berkembang menjadi pusat kekuatan ekonomi. Media sosial merupakan suatu sarana digital marketing yang paling mudah untuk dimanfaatkan dalam pengembangan UMKM. Bahkan media sosial menjadi pintu pembuka usaha UMKM untuk berkomunikasi dengan jutaan orang mengenai produk sekaligus menciptakan pemasaran baru.

Strategi digital marketing ditengarai berpengaruh hingga 78 persen terhadap keunggulan bersaing UMKM dalam memasarkan produknya (Wardhana, 2015). Selain beaya murah dan tidak memerlukan keahlian khusus dalam melakukan inisiasi awal, media sosial dianggap mampu secara langsung meraih (engage) calon konsumen. Hal ini ditandai, di antaranya dengan sikap pelaku usaha yang mulai lebih menitikberatkan pemanfaatan media sosial dibanding pengembangan situs.

Di kabupaten Bantul, salah satu kabupaten di DI Yogyakarta, potensi UMKM cukup menjanjikan. Industri pengolahan makanan tercatat di "Bantul dalam Angka 2017" jumlahnya mencapai 8.290 unit usaha. Di balik potensi tersebut, terdapat sejumlah tantangan seperti kurangnya ketrampilan dan pengetahuan pelaku usaha, minimnya modal dan jaringan pemasaran yang terbatas. Pre-survey peneliti menunjukkan bahwa sebagian kecil pelaku UMKM perikanan telah menggunakan digital marketing. Dengan kemampuan yang terbatas, pelaku usaha yang tergolong early adopter tersebut lebih sering mengoptimalkan Whats App dan Facebook untuk membantu transaksi perdagangan selain dengan cara konvensional. Berangkat dari latar belakang tersebut, bagaimana upaya Dinas Pertanian Tanaman Pangan Kelautan dan Perikanan Kabupaten Bantul dalam mengoptimalikan pengelolaan dan pemasaran Produksi Perikanan? Bagaimana akses UMKM perikanan terhadap digital marketing?

\section{TINJAUAN PUSTAKA}

\section{Digital Marketing}

American Marketing Association (AMA) mendefinisikan Digital Marketing sebagai rangkaian aktifitas institusi dan proses yang difasilitasi oleh teknologi digital dalam menciptakan, mengkomunikasikan, menyampaikan nilai-nilai kepada konsumen dan pihak yang berkepentingan lainnya (Kannan dan Hongshuang, 2016).

Secara sederhana, digital marketing juga dapat diartikan sebagai kegiatan promosi dan pencarian pasar melalui media digital secara online dengan memanfaatkan berbagai sarana jejaring sosial (Dedy, dkk. 2017). Adapun ciri-ciri kegiatan digital marketing menurut Stockdale (2012) sebagai berikut.

1. Interactivity, kemampuan perangkat teknologi menfasilitasi komunikasi antar individu. Komunikasi dapat terjalin interaktif sehingga para komunikator dapat berkomunikasi dengan lebih akurat, efektif dan memuaskan.

2. Demassification, pesan atau informasi dapat dipertukarkan atau disampaikan kepada partisipan yang terlibat dalam jumlah besar. 
3. Asynchronous, teknologi komunikasi mempunyai kemampuan untuk mengirim dan menerima pesan pada waktu yang dikehendaki setiap peserta.

Menurut Wardhana (2015) digital marketing memiliki sejumlah strategi dalam memasarkan produk. Strategi tersebut terdiri dari: ketersediaan informasi produk dan paduan produk; gambar-gambar atau ilustrasi produk; video; lampiran dokumen-dokumen yang berisi informasi dalam berbagai format dan komunikasi online dengan pengusaha; ketersediaan alat transasksi dan variasi media pembayaran. Bahkan melalui media sosial disediakan fitur bantuan dan layanan konsumen, dukungan opini online, tampilan testimonial, pencarian produk, yang kesemuanya memudahkan dan memanjakan konsumen.

\section{Aksesibilitas Teknologi Informasi dan Kendalanya}

Di Era Revolusi Industri 4.0, literasi digital menjadi amat krusial bagi masyarakat. Masyarakat ibaratnya harus melek informasi atau yang disebut dengan masyarakat informasi yaitu komunitas bangsa yang tidak dapat lepas dari teknologi informasi. Dengan ragamnya kondisi masyarakat, disparitas pembangunan, persoalan kesenjangan digital antara laki-laki dan perempuan terbentang nyata.

Suwana dan Lily (2017) dalam penelitiannya menunjukkan bahwa perempuan sebagai pengguna internet yang aktif namun memiliki literasi yang rendah hal ini disebabkan oleh latar belakang pendidikan yang rendah, kurangnya fasilitas, kurangnya latihan dan besarnya pengaruh budaya patriarkhi (Gaib, dkk. 2017). Hambatan demikian dapat diperbaiki dengan menekankan pendidikan pada kaum perempuan dan laki-laki, sama-sama memiliki peran yang penting dalam peradaban manusia dan pembangunan bangsa.

Kesenjangan digital menurut Molar (dalam Hadiyat, 2014) memiliki tiga tipe yakni acces divide, usage divide dan quality of use divide. Acces divide berkaitan dengan kesenjangan kepemilikan akses terhadap teknologi informasi. Sedangkan usage divide berupa kesenjangan pada perbedaan penggunaan teknologi informasi. Quality of use divide berupa kesenjangan terhadap kualitas dari penggunaan teknologi dalam keseharian. Kesenjangan dalam hal penggunaan teknologi itu sendiri terkait dengan stereotip yang melekat di masyarakat bahwa teknologi lebih dekat dengan kehidupan laki-laki, kurangnya adanya ketertarikan dan kurangnya kapabilitas untuk menggunakannya (Suwana dan Lily, 2017).

Untuk mencapai cita-cita global SDG's, salah satunya kesetaraan gender, kesenjangan digital ini tidak dapat dibiarkan semakin lebar. Kesenjangan digital ini dapat diatasi dengan literasi digital yang menyangkut lima aspek meliputi access, analyse and evaluation, reflection and action (Suwana dan Lily, 2017). Artinya, perempuan tidak hanya dituntut dapat menggunakan media dengan terampil, memahami dan berpikir kritis dengan bantuan media digital. Akan tetapi juga bertindak ataupun berkolaborasi berbagi pengetahuan dengan sarana teknologi dalam memecahkan berbagai persoalan kehidupannya.

\section{METODE PENELITIAN}

Penelitian ini menggunakan pendekatan kualitatif deskriptif. Berdasarkan jenis penelitian ini, memungkinkan dihasilkan data sistematis dan terencana dari awal hingga akhir penelitian. Selain itu penelitian dapat dikembangkan berdasarkan telaah lapangan secara langsung dan mengambil data kepada narasumber. Metode deskriptif dipakai untuk memberi gambaran mengenai realitas yang ada pada sumber data baik secara verbal maupun non verbal. Teknik pengumpulan data berupa indepth interview, teknik dokumentasi (penelusuran data sekunder), FGD (Focus Group Discussion) dan observasi partisipatoris. FGD relevan digunakan dalam penelitian sosial untuk menggali data secara general dan lebih efisien karena mampu insight kepada narasumber melalui penafsiran suatu peristiwa dan perilaku sosial.

Observasi di UMKM perikanan dilakukan sebagai bagian untuk triangulasi data. Teknik pengambilan data key informan dengan teknik purposive sampling. Key informan meliputi: pengurus paguyuban Projo Mino Bantul, penyuluh dan penyuluh kontrak, Kepala Seksi Dinas Pertanian Tanaman 
Pangan Kelautan dan Perikanan (Dipertautkan) Kabupaten Bantul, Sekretaris Dinas Kelautan dan Perikanan DIY dan anggota kelompok pengolah dan pemasar ikan.

Teknik analisis data kualitatif merujuk konsep Milles and Huberman (2007) meliputi empat tahapan di dalam proses analisis data yang meliputi (a) pengumpulan data; b) reduksi data. Beberapa data dipilih dan diambil sesuai dengan data yang relevan untuk menjawab rumusan masalah penelitian; c) penyajian data; d) simpulan dan verifikasi. Teknik ini relevan karena dianggap memungkinkan reduksi data dari berbagai data yang digunakan dalam triangulasi. Teknik triangulasi metode digunakan dalam penelitian ini, yakni peneliti membandingkan data hasil FGD dan observasi dengan data serupa yang dilakukan melalui indepth interview dan penyebaran angket kepada peserta FGD. Angket ditujukan untuk memperkuat data hasil FGD maupun observasi.

\section{HASIL DAN PEMBAHASAN}

\section{Deskripsi Obyek Penelitian}

Di Kabupaten Bantul, potensi UMKM cukup menjanjikan dengan menyumbang pendapatan aset daerah, penyerapan tenaga kerja dan meningkatkan kesejahteraan masyarakat. Salah satu UMKM berpotensi adalah industri pengolahan makanan. Hal ini ditunjukkan dalam "Bantul dalam Angka 2017", bahwa jumlah industri pengolahan makanan mencapai 8.290 unit usaha dengan serapan tenaga kerja 27.480 orang. Kontribusinya pada pendapatan daerah mencapai 311.697.255.000 rupiah. Dengan kata lain, industri pengolahan makanan dapat mengurangi pengangguran dengan penyerapan tenaga kerja yang cukup banyak dan memberi kontribusi terhadap perekonomian setempat.

UMKM perikanan menjadi bagian penting dari industri pengolah makanan merupakan kelompok usaha yang beranggotakan pengolah dan pemasar ikan di kabupaten Bantul. Produk usaha yang selama ini dihasilkan adalah olahan makanan berbahan baku ikan laut hasil tangkapan di kabupaten Bantul maupun yang dipasok dari luar daerah Bantul jika terjadi musim paceklik. Produk unggulannya berupa: krupuk ikan, empek-empek, tahu bakso, bandeng presto, fish jelly (otak-otak, takoyaki dsb) dan bakso. Produksi yang dilakukan UMKM perikanan sebagian besar masih tergantung pemesanan pelanggan.

Pemasaran produknya pun masih bergantung pada mouth by mouth, belum sepenuhnya bersentuhan dengan teknologi informasi atau online. Selain melayani pemesanan, cara pelaku usaha memasarkan produk dengan cara menitipkan hasil produksinya pada gerai rumah makan atau pada gelaran pameran ekbis di daerahnya yang frekwensinya tidak menentu. Dengan demikian, dari sisi pendapatan omzet penjualan tidak menentu dan hal ini berdampak pada permodalan usaha.

Saat musim anak-anak masuk sekolah atau menjelang hari Raya Islam, kebutuhan pelaku usaha meningkat maka modal usaha akan digunakan untuk memenuhi kebutuhan rumah tangga dan sekolah anak. Kontinuitas usaha terhenti sejenak karena mereka harus berhenti berproduksi. Sebaliknya pada saat menjelang hari Raya dan musim liburan, permintaan oleh-oleh/cindera mata berbahan ikan melonjak baik dari dalam kota maupun luar kota. Pesanan tidak dapat dipenuhi oleh pelaku usaha selain karena modal terbatas, UMKM kesulitan mencari bahan baku karena aksesibilitas terbatas.

Persoalan permodalan sebenarnya dapat diatasi oleh pelaku usaha melalui akses perbankan akan tetapi pihak bank tidak memberi kesempatan pada pengusaha mikro ini karena dari sisi pembukuan memang masih kurang. Kelemahan UMKM pada umumnya, belum dapat memisahkan aset rumah tangga dan aset usaha. Mereka belum memiliki pembukuan yang benar seperti buku kas, buku pembelian, buku penjualan dan buku harian. Jaringan usahanya masih terbatas, belumlah begitu luas, yang menjamin pasokan bahan baku secara rutin baik pada saat musim ikan maupun paceklik ikan.

Tenaga kerja UMKM, sebagian besar merupakan anggota keluarga yang rata-rata perempuan dengan ketrampilan dan kemampuan terbatas. Dengan keterbatasan tersebut, keinginan berproduksi ada, namun kurang inovatif karena keterbatasan modal, takut akan perubahan dan kerugian pada usaha yang ditekuninya. Ketiadaan modal yang leluasa mengakibatkan mereka enggan 
mencoba diversifikasi menu olahan. Sisi lain, perkembangan pasar dan selera konsumen kian beragam, termasuk menu makanan berbahan baku ikan. Selain haus inovasi, masyarakat mulai mementingkan higienis dan kemasan menarik.

Selain data di atas, dari Focus Group Discussion (Januari, 2018) terungkap bahwa UMKM perikanan menghadapi sederet tantangan: sarana prasarana yang kurang, produk yang belum terstandarisasi, banyak yang belum memiliki ijin PIRT (Pangan Industri Rumah Tangga) dan sistem pemasaran yang konvensional.

\section{Optimalisasi Pengelolaan dan Pemasaran Produksi Perikanan}

Indikator produktifitas bidang perikanan suatu daerah terlihat dari produksi perikanan budidayanya. Pada tahun 2017 produksi perikanan budidaya Pemkab Bantul mengalami kenaikan sebesar 5,84\% dari $11.363 .723 \mathrm{~kg}$ pada tahun 2016 menjadi $12.027 .220 \mathrm{~kg}$ pada tahun 2017. Kenaikan ini disebabkan karena introduksi teknologi baru yaitu budidaya ikan hemat lahan dan air (MATLAIR) (Laporan Kinerja Dipertautkan Bantul 2017). Teknologi ini mengutamakan lahan terbatas dan padat tebar tinggi dan terbukti mampu meningkatkan produksi perikanan budidaya di Kabupaten Bantul. Data produksi perikanan budidaya Kabupaten Bantul Tahun 2015-2017 disajikan pada Tabel I.

Tabel 1. Produksi Perikanan Budidaya Kabupaten Bantul tahun 2015-2017

\begin{tabular}{|c|c|c|c|c|}
\hline No & $\begin{array}{l}\text { Jenis } \\
\text { Ikan }\end{array}$ & 2015 & 2016 & 2017 \\
\hline 1 & Gurami & 2.038 .280 & 1.860 .867 & 2.028 .830 \\
\hline 2 & Nila & 2.231 .763 & 1.924 .565 & 2.114 .000 \\
\hline 3 & Lele & 6.106 .252 & 6.738 .202 & 7.094 .430 \\
\hline 4 & Bawal & 218.462 & 258.883 & 282.250 \\
\hline 5 & Patin & 95.597 & 40.150 & 29.370 \\
\hline 6 & Mas & 24.268 & 34.018 & 37.450 \\
\hline 7 & $\begin{array}{l}\text { Udang } \\
\text { Vaname }\end{array}$ & 650.602 & 507.038 & 440.890 \\
\hline \multirow[t]{2}{*}{8} & Lain & - & - & - \\
\hline & Jumlah & 11.365 .224 & 11.363 .723 & 12.027 .220 \\
\hline
\end{tabular}

Sumber: Dinas Pertanian Pangan Kelautan dan Perikanan, 2018.
Tabel 1 menunjukkan produksi lele menjadi andalan perikanan budidaya kabupaten Bantul, disusul produksi ikan nila dan ikan gurami. Produksi tersebut membantu suplai ikan dan lele pada rumah makan dan industri olahan di wilayah Bantul dan sekitarnya.

Berbagai kegiatan untuk mendukung pengolahan dan pemasaran produksi perikanan telah dilaksanakan tahun 2016 antara lain:

1. Fasilitasi poklahsar dalam mengikuti pameran-pameran yang bertujuan untuk meningkatkan promosi dan memperluas jaringan pemasaran produk UMKM perikanan: Pekan Produk Unggulan dan Investasi Nusantara April 2016; Malang Investment Trade and Tourism Expo, Mei 2016 dan Pameran Hari Pangan Sedunia, September 2016

2. Penyuluhan peningkatan konsumsi hasil perikanan disertai dengan lomba masak ikan dan kampanye makan ikan

3. Lomba UMKM pemasar perikanan untuk meningkatkan manajemen dan pengelolaan usaha hasil perikanan.

4. Temu usaha pelaku usaha kelautan dan perikanan untuk meningkatkan jejaring pemasaran UMKM di bidang kelautan dan perikanan

5. Gerakan memasyarakatkan makan ikan atau Gemar Ikan di sekolah Paud dan TK, dan di 17 TP PKK kecamatan di kabupaten Bantul dengan jumlah peserta 2.100 orang.

6. Fasilitasi UMKM perikanan dalam menggunakan Depo Kuliner (kantor lama) sebagai pusat inkubator minabisnis dengan kegiatan pelatihan dan pusat kuliner serba ikan (Laporan Kinerja Dipertautkan Bantul 2016).

\section{Keseluruhan program Optimalisasi}

Pengelolaan dan Pemasaran Produksi Perikanan tersebut menelan dana sebesar Rp.836.670.000,-

Pada tahun 2017, Dipertautkan Bantul berupaya melakukan optimalisasi pengelolaan dan pemasaran hasil perikanan, Program ini dengan memanfaatkan SDM, teknologi dan anggaran sebesar $R p$ 45.935.000,- (Laporan Kinerja Dipertautkan Bantul 2017). Hasil program tersebut antara lain: terlaksananya promosi hasil produksi perikanan dan kelautan, pelatihan poklahsar guna meningkatkan skill dan ketrampilannya, 
FGD di bidang sosialisasi perijinan usaha perikanan. Outcomenya, diharapkan berupa peningkatan volume produk olahan hasil perikanan yang meningkatkan kesejahteraan nelayan.

Dalam pencapaian sasaran meningkatnya produksi perikanan, pemkab Bantul berhasil meraih prestasi juara 1 tingkat nasional Penghargaan atas Evaluasi Kinerja Tenaga Pendamping Lembaga Pengelola Modal Usaha Kelautan dan Perikanan (LPMUKP) atas nama Fakhrudin Al Rozi. LPMUKP merupakan satuan kerja Kementerian Kelautan dan Perikanan yang menerapkan pola pengelolaan Badan Layanan Umum (BLU) dengan tugas utama menyalurkan pinjaman atau pembiayaan dana bergulir yang berpendampingan kepada usaha kecil mikro dan menengah Kelautan dan Perikanan (Laporan Kinerja Dipertautkan Bantul tahun 2017).

Di balik prestasi tersebut, data di lapangan menunjukkan masih dijumpai sejumlah persoalan dari sisi ketrampilan pemasar. Pemasar ikan masih banyak yang tidak menggunakan sistem rantai dingin. Hal ini menurut sejumlah informan, mereka tidak memiliki cooler box dan daya listrik tidak terjangkau. Untuk mengatasi hal ini maka para pemasar dan pengolah kuliner menyimpan stock ikan seperlunya saja untuk mengatasi kerugian olahan.

Cara yang lain, mereka 'meminjam' ikan dari tengkulak yang memiliki cooler box. Pembayarannya akan dilakukan setelah dagangan atau produksinya laku. Ketergantungan ini yang semakin menyulitkan para poklahsar terlepas dari belitan para tengkulak-tengkulak besar. Strategi ini dipakai para tengkulak untuk menekan hasil pasca panen sehingga merugikan pemasar kecil.

Kegiatan lain dari Dipertautkan Kabupaten Bantul dalam monitoring dan uji mutu hasil perikanan adalah peningkatan kesadaran masyarakat mengenai pentingnya menjaga keamanan dan kesehatan produk perikanan yang diolah atau dipasarkan. Kegiatan ini dilaksanakan di 14 lokasi pasar tradisional. Dari hasil pengujian boraks dan formalin terhadap beberapa sampel, tidak ditemukan adanya ikan yang mengandung boraks dan formalin. Hasil monitoring mutu produk perikanan ini disosialisasikan kepada pedagang ikan. Selain itu, juga dilakukan pembinaan terhadap pedagang ikan agar tidak menggunakan bahan berbahaya. Kegiatan sosialisasi larangan penggunaan bahan tambahan pangan berbahaya yang dilarang dalam produk perikanan digalakkan pada bulan Maret-Oktober 2016, frekwensi tujuh kali dengan peserta 210 orang.

Berdasarkan pengamatan tim peneliti dan data-data tahun 2016-2017 nampak bahwa orientasi Dipertautkan Kabupaten Bantul lebih memprioritaskan pada peningkatan produksi perikanan budidaya. Persoalan pemasaran produk UMKM perikanan kurang disentuh dan pada umumnya dilakukan secara konvensional. Pertimbangan prioritas bahwa petani budidaya lebih mudah dikembangkan sementara produksi UMKM olahan perikanan masih terbatas dengan jaringan pasar belum berkembang luas.

Selain itu, akibat penataan kelembagaan di tahun 2017, yakni sejak Dinas Perikanan dan Kelautan Kabupaten Bantul bergabung dengan Dinas Pertanian dan Tanaman Pangan maka kewenangan pelatihan poklahsar dan pengembangan bina usaha kelompok pemasar dan pengolah perikanan di bawah koordinasi Dinas Kelautan dan Perikanan Propinsi DIY. Akibatnya, terdapat celah yang tidak terisi dalam pemberdayaan UMKM perikanan. Kewenangan Dipertautkan dalam pemberdayaan poklahsar terbatas baik dari sisi penganggaran maupun pemberian dampingan penyuluhan.

Ramainya transaksi market place di media sosial maupun di pusat perbelanjaan daring menunjukkan fakta yang berbeda. Tidak sedikit netizen menanyakan produk-produk berbahan ikan yang berkualitas. Sebaliknya dari kalangan pelaku usaha UMKM perikanan, tidak sedikit yang kreatif dan berani memasarkan secara online. Kondisi ini belum mendapat perhatian serius dari Dipertautkan Kabupaten Bantul dalam mengoptimalkan pemasaran produk perikanan pasca panen.

\section{Aksesibiltas UMKM Perikanan dalam Penerapan Digital Marketing}

Perihal penerapan digital marketing dalam pemasaran, tim peneliti mengambil data dari 100 responden anggota Paguyuban Projo Mino, pengurus dan pelaku UMKM perikanan. Kepada responden ditanyakan tentang hambatan penerapan digital marketing. Survey sederhana menunjukkan, dalam 
penerapan digital marketing, sebagian besar (65 persen) belum menerapkan digital marketing, baik dalam pengelolaan keuangan maupun transaksi penjualan/pemasaran produk karena kurang memahami internet. Pertimbangan yang lain tidak digunakannya digital marketing karena tidak memiliki tenaga SDM di bidang TI (Teknologi Informasi) 10\%, tidak memiliki strategi bisnis melalui internet $5 \%$.

Tabel 2. Persoalan UMKM perikanan dalam Penerapan Digital Marketing

\begin{tabular}{|c|c|c|}
\hline No & Keterangan & $\%$ \\
\hline 1 & $\begin{array}{l}\text { Tidak memiliki tenaga SDM di } \\
\text { bidang } \\
\text { Informasi) }\end{array}$ & 10 \\
\hline 2 & Kurang memahami internet & 65 \\
\hline 3 & Tidak sesuai dengan produk & 5 \\
\hline 4 & $\begin{array}{l}\text { Tidak memiliki strategi bisnis } \\
\text { di internet }\end{array}$ & 5 \\
\hline 5 & $\begin{array}{l}\text { Tidak percaya dengan } \\
\text { transaksi on line }\end{array}$ & 5 \\
\hline 6 & $\begin{array}{l}\text { Kurang bermanfaat bagi } \\
\text { pengusaha }\end{array}$ & 10 \\
\hline
\end{tabular}

Data Primer 2017

Melalui wawancara mendalam dan data angket menunjukkan, 5\% pelaku usaha tidak percaya dengan keamanan transaksi elektronik. Maraknya cerita-cerita penipuan melalui transaksi online membuat pelaku usaha takut untuk berbisnis dengan sistem online.

Ditemukan pula pertimbangan bahwa pelaku usaha merasa digital marketing tidak sesuai dengan produk yang ditawarkan (5\%). Untuk point terakhir, pada umumnya adalah pelaku usaha dengan jaringan terbatas dan tenaga kerja terbatas. Dengan modal yang terbatas, tidak mampu membayar tenaga kerja baru sehingga pesanan maupun produksi pun terbatas.

Observasi peneliti menemukan bahwa rata-rata UMKM memiliki tenaga kerja dari keluarga atau kerabat dekat. Pelaku usaha yang tergolong early adopter masih menggunakan WA, Facebook, Twitter dan IG, sebagian besar sebagai sarana aktualisasi diri dan bersilaturahmi. Mereka menilai bahwa bisnis online kurang bermanfaat untuk memasarkan produknya sebesar $10 \%$ (tabel 2). Dalam hal ini, pelaku usaha perlu didorong untuk memanfaatkan digital marketing bukan semata menunjang pemasaran saja namun juga untuk pencarian bahan baku, memetakan pasar, mengendalikan stabilitas harga dan memperluas jaringan bisnis.

Pemkab Bantul yang tengah mengembangkan ekonomi kreatif, secara khusus wisata kuliner, dapat mengoptimalkan modal sosial melalui media sosial untuk membantu pemasaran wisata kuliner dan produk UMKM perikanan. Fenomena menarik bahwa sebagian kecil produk UMKM perikanan telah mengisi gerai oleh-oleh di pusat Kota Bantul meski sebagian lagi masih terpaku pada promosi mandiri.

Lemahnya pendampingan pada kelompok pemasar ikan, minimnya pendampingan literasi digital usai pelatihan-pelatihan yang telah diselenggarakan Dinas Perikanan dan Kelautan DIY, mengakibatkan pelaku UMKM kurang optimal dalam menerapkan digital marketing.

Kelompok-kelompok yang sudah dilatih dalam observasi nampak tidak memberi akses kepada pemasar yang lain untuk mengikuti pelatihan-pelatihan teknologi informasi maupun membagi informasi yang telah diterima. Akibatnya, kontinuitas program yang diharapkan, tidak tercapai. Ke depan, Dinas Pertanian Tanaman Pangan, Kelautan dan Perikanan Kabupaten Bantul seyogyanya dalam pemberian pelatihan, penentuan pemberian bantuan dana ataupun teknologi diprioritaskan poklahsar dengan prestasi baik. Selanjutnya kelompok tersebut diwajibkan memberikan akses bagi wirausaha baru atau warga pesisir yang akan bergerak di bidang yang sama. Dengan cara ini, paguyuban poklahsar yang berhasil dapat menjadi payung sosial dan ekonomi bagi kelompok yang rentan atau kurang mampu di pesisir.

Posisi penyuluh dalam naungan Dinas Pertanian, Tanaman Pangan, Kelautan dan Perikanan Kabupaten Bantul menjadikan posisinya tidak mandiri dan lebih sering dibebani oleh pekerjaan administrasi. Hal inilah yang mengakibatkan proses literasi digital marketing tidak berjalan optimal. Jam penyuluhan sesuai jam kantor juga menjadi penghalang bagi para pelaku UMKM perikanan untuk mengikuti berbagai pelatihan karena mereka lebih mementingkan pekerjaan rumah atau berjualan (wawancara 
dengan ibu S, Januari 2018). Dengan demikian, perlu kiranya dipikirkan waktu dan cara pelatihan digital marketing yang tepat, khususnya bagi pelaku usaha yang rata-rata adalah perempuan.

Ketika peneliti menanyakan tentang kerjasama dengan pusat perbelanjaan on line yang terkenal seperti Go Food; Buka Lapak, hasil wawancara dengan key-informan mendapat komentar yang cukup beragam:

"ingin, sempat berdiskusi dengan mereka (manajemen) tapi dari Go-Food belum datang lagi", (wawancara ibu Sumarsih, Februari 2018).

"wah sulit, karena mereka minta 30 persen, produk saya jatuhnya jadi mahal" (wawancara ibu Sukismi, Februari 2018)

Dengan demikian, keinginan mengembangkan pemasaran dengan digital marketing dari pelaku usaha cukup besar usai mendapatkan pelatihan. Di sinilah pentingnya fasilitasi pendampingan pemerintah atau pun swasta perlu terus dilakukan agar permasalahan acces hingga reflection and action pada digital marketing sebagaimana konsep Suwana \& Lily (2017) dapat tercapai.Tanpa kepedulian swasta, perguruan tinggi dan pendampingan dari pemerintah, percepatan literasi digital bagi UMKM menjadi suatu kemewahan di era industri 4.0.

\section{KESIMPULAN}

UMKM perikanan di kabupaten Bantul sebagian besar belum menerapkan e-commerce, baik dalam pengelolaan keuangan maupun transaksi penjualan/pemasaran produk. Langkah strategis bagi penguatan UMKM dapat ditempuh melalui penambahan frekwensi pelatihan, studi banding dan mengintensifkan pendampingan pada kelompok. Pendampingan literasi digital marketing tersebut dapat diprakarsai swasta, perguruan tinggi maupun pemerintah. Kerja sama yang dirintis dengan pusat perbelanjaan daring, selain dengan pengusaha lokal, akan dapat menambah jaringan usaha UMKM perikanan.

Melalui kemitraan usaha bersama tersebut dapat berfungsi sebagai media pembelajaran untuk menghasilkan komoditi yang sesuai dengan selera pasar. Sedangkan penguatan jejaring dimaksudkan untuk mendekatkan, memperluas pasar dan memperkuat modal serta bermanfaat nantinya bagi standarisasi harga dan mutu produk.

\section{DAFTAR PUSTAKA}

APJII, A.P.PJ.I.I. (2016). Penetrasi dan Perilaku Pengguna Internet Indonesia 2016) (apjii.or.id).

Purwana, D., Rahmi, R., \& Aditya, S. (2017). Pemanfaatan digital marketing bagi usaha kecil mikro dan menengah (UMKM) di kelurahan Malaka Sari, Duren Sawit. Jurnal Pemberdayaan Masyarakat Madani (JPMM) 1(1), 1-17.

Hadiyat, Y. D. (2014). Kesenjangan Digital di Indonesia Digital Divide in Indonesia (Case Study in Wakatobi-Regency). Jurnal Pekomas, 17(2014), 81-90. Retrieved from http://download.portalgaruda.org/ article.php?article $+278889 \&$ val $=6557 \&$ title $=$ Kesenjangan Digital di Indonesia

Gaib, H., dkk. (2017). Profil Perempuan Indonesia 2017 (Santosa Didiek, Ed.) Jakarta: KP3A.

Kannan, P. K. \& Hongshuang, L. (2016). Digital marketing: A framework, review and research agenda. International Journal of Research in Marketing

Miles, M. B., \& Huberman, A. M. (2007). Analisis data kualitatif buku sumber tentang metode-metode baru. Terjemahan Tjetjep Rohendi Rohisi. Jakarta: Universitas Indonesia.

Stockdale, R., Ahmed, A., \& Scheepers, H. (2012). Identifying Business Value from the Use of Social Media: An SME Perspective. In Pasific Asia Conference on Information Systems. Association for Information System Electronic Library

Suwana, F., \& Lily (2017). Empowering Indonesian women through building digital media literasi. Kasetsart Journal of Social Sciences, 38(3), 212-217. DOI: 10.1016/j.kjss.2016.10.004

Wardhana, A. (2015). Strategi Digital Marketing dan Implikasinya pada Keunggulan Bersaing UKM di Indonesia

Laporan:

Bantul dalam Angka 2017. 
Laporan Kinerja Dinas Pertanian dan Tanaman Pangan Kelautan dan Perikanan Kabupaten Bantul tahun 2016.

Laporan Kinerja Dinas Pertanian dan Tanaman Pangan Kelautan dan Perikanan Kabupaten Bantul tahun 2017 
Anggraini \& Supriyanto / Literasi Digital: Sesuatu Kemewahan bagi UMKM ... 